\title{
ФОРМУВАННЯ ТОВАРНОЇ КАТЕГОРІЇ МАСЛА ОРГАНІЧНОГО
}

\begin{abstract}
Анотація. На основі проведених досліджень було проаналізовано стан ринку товарної категорії органічного масла вершкового в Україні та світі за рахунок детального збору інформації на іноземних інтернет-ресурсах, Міжнародному сайті збору статистичної інформації стосовно даного виду товару, а також опрацьовано десятки статей та навчальна література; визначено чинники формування товарної категорії органічного масла шляхом критичного аналізу зібраної інформації в електронних журналах, де попередньо здійснено опитування стосовно защікавленості споживачів в органічній продукщії, критерії, якими вони керуються при виборі та фрактори, що заважають регулярно здійснювати покупку масла вершкового органічного; виокремлено переваги, особливості масла органічного вершкового, що позитивно впливають на організм людини.
\end{abstract}

Ключові слова: ринок органічної продукції, товарна категорія масла вершкового органічного, споживчі переваги, формування попиту, харчова та біологічна цінність.

Shapovalova Nataliia, Volosian Karolina

Kyiv National University of Trade and Economics

\section{FORMATION OF COMMODITY CATEGORY OF ORGANIC BUTTER}

Summary. Promotion of organic products due to the transition of consumers to a conscious healthy diet, the problems of formation of the commodity category of organic oil in Ukraine and possible ways to solve them are now timely and relevant. Based on the research, the state of the market of organic butter in Ukraine and the world was analyzed through detailed collection of information on foreign Internet resources, the International site for collecting statistical information on this type of product, as well as a large number of articles and educational literature. According to the results, the most active consumers are the countries of the European Union, in particular France. However, due to the conditions of the pandemic situation, there was a decrease in demand for organic products in Germany. Ukraine has great potential in the niche of organic production and has some achievements, namely, there has been a rapid growth in the production of organic dairy products. The factors that negatively affect the development of the Ukrainian market of organic food products, in particular organic oil, were analyzed in the research. The paper also highlights the factors of formation of the commodity category of organic oil by critical analysis of information collected in electronic journals, which previously conducted a survey on consumer interest in organic products, their product selection criteria and factors that prevent regular purchase of organic butter; the advantages, features of organic butter that have a positive effect on the human body are highlighted. Moreover, the paper provides recommendations for the development of the commodity category of organic butter in Ukraine through more active public awareness of the usefulness and safety of organic butter, its value, consumer benefits, positive impact on economic, social and environmental spheres of activity. It is recommended to involve government agencies, investments, environmental associations and consumer organizations in the process of forming a market for organic products. Furthermore, it is significant to adopt experience in organizing sales, building market infrastructure, forming sales channels, pricing policy for organic butter in countries around the world that are successful in the organic industry. This will help restore soil fertility and preserve the environment; development of agricultural areas and raising the living standards of peasants; profitability and efficiency of agricultural production; providing the consumer market with quality, healthy products; strengthening the export potential of the state; improving the image of the Ukrainian manufacturer; ensuring food security in Ukraine; improving the general well-being of the country's citizens.

Keywords: market of organic products, commodity category of organic butter, consumer preferences, demand formation, nutritional and biological value.

Постановка проблеми. Протягом останніх років тематика здорового способу життя $є$ надзвичайно популярною, високий рівень екологічної свідомості населення та низка екологічних чинників сорормували передумови для розвитку ринку органічної продукції в Україні. Проблема переповнення внутрішнього ринку низькоякісними, фральсифікованими товарами стимулюе споживачів купувати органічні продукти як альтернативу звичайним, особливо це стосуеться продуктів щоденного вжитку, серед яких молочні.

Товарна категорія масла вершкового органічного, що представлене в Україні, має недостатньо сорормований асортимент, порівняно з традиційним, оскільки даний вид молочної продукції лише нещодавно з'явився на вітчизняному рин- ку, проте поступово впроваджуеться та займає ряди серед продуктів в споживчому кошику.

Аналіз останніх досліджень і публікацій. Сучасний стан і перспективи розвитку ринку органічної продукції аналізували в своїх роботах Берсуцька С.Я., Козичева Т.О. [7], досліджували споживачів органічної продукції Ковальчук С.В., Забурмеха С.M. [8], формування інструментарію впровадження та просування органічної продукції на споживчі ринки було висвітлено в роботі Вінюкова О.Б. [12], здійснили оцінку ринку органічної продукції України та поведінку споживачів на ньому Семенда Д.К., Семенда О.В. [13].

Мета статті. Головною метою цієї роботи $є$ формування товарної категорії органічного масла.

Виклад основного матеріалу. Органічне вершкове масло - це натуральні збиті вершки без 
стабілізаторів, ароматизаторів, барвників та харчових добавок, в процесі виробництва даного продукту використовуються речовини та процеси лише природнього походження, а також ретельно підібрані методи переробки, при цьому, обов'язковою умовою є сертифрікація та відповідність всіх етапів виготовлення детально прописаним постановам про органічне виробництво Свропейського Союзу.

Органічний сертифікат гарантуе: простежуваність виробництва органічного харчового продукту; технологічний процес виготовлення щорічно проходить перевірку на відповідність органічним стандартам [1].

Основними гравцями на світовому ринку масла вершкового органічного е такі виробники Horizon Organic, Aurora Organic Dairy, General Mills Inc., Arla Foods Amba i Organic Valley, а також інші [2].

В Свропі, простежується тенденція зростання продажів органічної молочної продукції, зокрема у Франції, за даними EuroCommerce, за останні роки зросло споживання органічного вершкового масла на 23,2\%. В цілому продаж молочних продуктів займає більше $17 \%$ від усього органічного ринку Франції, в структурі 7,5\% - молоко, 3,4\%масло вершкове і йогурти, $1,5 \%$ - вершки, молоді сири $-1,1 \%$, звичайні сири - 0,5\% [3].

В зв'язку з пандемією, в Німеччині зафіксовано зниження попиту на органічну продукцію. За результатами опитування, в 2018 р. - 28\% споживачів регулярно купували органічну продукцію, в 2019 р. близько 49\%, а в 2020 р. цей показник зменшився на $12 \%$ і становив $37 \%$, при цьому найчастіше споживають яйця та молочні продукти (51\%), серед яких масло вершкове органічне - 4,5\%. Але автори зазначають, що ця тенденція є тимчасовою [4].

В Австрії масло вершкове органічне становить 10,8\% від всього ринку органічної продукції, в Норвегії - 3,1 \% за даними дослідного інституту органічного сільського господарства (FiBL) [5].

Україна має великий потенціал в ніші органічного виробництва і має певні результати. За даними «Organic Standard», що е членом Міжнародної Федерації органічних сільськогосподарських рухів (IFOAM) та Союзу Свропейських Органічних Сертифікаційних Органів (EOCC), станом на 2019 р. в Україні сертифіковано 384,5 тис. га органічних земель, налічува- лося 617 операторів органічного виробництва, в 2020 р. їх зафіксовано 722, на $17 \%$ більше ніж в попередньому, з них - чотири виробники органічної молочної продукщії, лише в асортименті трьох є масло вершкове органічне [6].

Експорт масла органічного з України збільшується здебільшого в країни СНГ та країни Азії, європейські країни купують органічне масло вершкове для кондитерської промисловості [7].

В світі купують органічну продукцію, в тому числі масло органічне, за такими причинами:

- в США споживачі вважають, що це допоможе їм бути більш здоровими;

- в Свропі споживачі піклуються таким чином про навколишне середовище;

- в КНР та в інших країнах Азії вважають, що органічні продукти - більш якісні та безпечні [8].

За прогнозами Міністерства аграрної політики та продовольства України, в структурі потенційного ринку органічних продуктів, молочні продукти, серед яких масло вершкове, будуть складати близько $12 \%$ (рис. 1).

Стрімкий розвиток ринку органічних продуктів харчування, в тому числі масла органічного, на сьогодні в Україні обмежують такі чинники:

1) складний процес органічної сертифікації за міжнародними стандартами, особливо Свропейськими;

2) недостатня фрінансова підтримка держави в даній сорері;

3) відсутне інформування населення, органів державної влади, виробників про перспективи розвитку, можливості впровадження та розповсюдження, користь органічної продукції;

4) недостатня кількість професійного досвіду, знань, щодо органічного виробництва, відсутня підготовка кваліфрікаційних кадрів;

5) вища цінова категорія, що в умовах економічної кризи, пандемії та неплатоспроможності населення знижує доступність для споживачів;

6) переважання експорту органічної продукції, низька асортиментна пропозиція в торговельних мережах України [8].

За даними Союзу виробників органічних сертифікованих продуктів «Органічна Україна", найбільшими підприемствами молочної продукції в Україні, серед якої масло вершкове органічне, е виробники - ТОВ «Органік Мілк» (TM «Organic Milk»), ПрАТ «ЕтноПродукт»

Молочні продукти,
масло вершкове
Хліб
—лія
— Фрукти і ягоди
- М'ясо і м'ясопродукти
Яйця
- Овочі

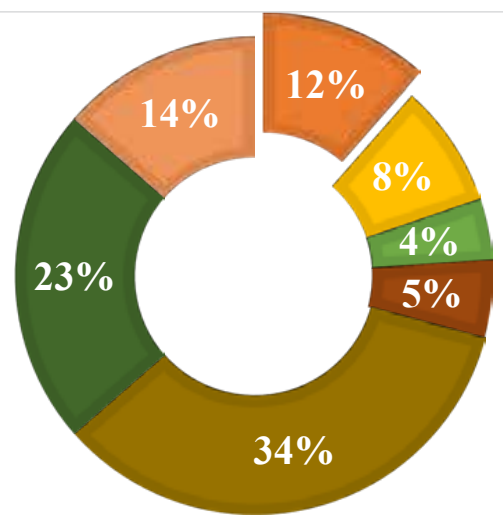

Рис. 1. Структура потенційного ринку органічної продукції в Україні 
Таблиця 1

Формування попиту на продукцію органічного походження

\begin{tabular}{|c|c|c|c|c|}
\hline Вікова група & $\begin{array}{c}\text { Овочі та фрукти, } \\
\text { \% }\end{array}$ & $\begin{array}{c}\text { М'ясна продукція, } \\
\mathbf{\%}\end{array}$ & $\begin{array}{c}\text { Молочна } \\
\text { продукція, \% }\end{array}$ & $\begin{array}{c}\text { Дитяче } \\
\text { харчування, \% }\end{array}$ \\
\hline $18-25$ років & 18 & 16 & 28 & 42 \\
\hline $26-35$ років & 39 & 40 & 32 & 55 \\
\hline $36-45$ років & 22 & 24 & 21 & 3 \\
\hline $46-54$ років & 16 & 14 & 11 & - \\
\hline 55 і більше & 5 & 6 & 8 & - \\
\hline
\end{tabular}

Джерело: [11]

(ТМ «ЕтноПродукт»), ТОВ «Старий Порицьк» (ТМ «Старий Порицьк») [6].

На формування товарної категорії масла органічного впливає споживчий попит. Споживачі віддають перевагу маслу органічному за високу харчову цінність, безпечність для здоров'я: без ГМО, гормонів, консервантів та антибіотиків.

За дослідженням вчених Університету Ньюкасла (Велика Британія), Учасників европейського дослідницького проекту Quality Low Input Food (QLIF) та Інституту продовольчих ресурсів НААН України масло органічне, порівняно зі звичайним вершковим, містить:

- на 50\% більше Омега-3 жирних кислот, які: понижують ризик серцево-судинних захворювань; підвищують розумові здібності; сповільнюють процес старіння;

- на $60 \%$ більше імунностимулюючих антиоксидантів;

- на $11 \%$ більше а-ліноленової кислоти, яка: корисна для здоров'я серця, так як понижує рівень холестерину; ефективно розщеплюе надлишкові жирові клітини;

- на $74 \%$ більше йоду;

- вміст незамінних амінокислот та замінних більший на $10,8 \%$ та $11,2 \%$ відповідно;

- вміст білку та «справжнього» білку більший на 2,04\% і 1,7\% відповідно;

- більше вітамінів та інших корисних мікроелементів, через м'яку пастеризацію під час обробки $\left(75^{\circ} \mathrm{C} \pm 2 \%\right)[1]$.

В Україні потенційними споживачами органічної продукції $є 5 \%$ населення великих міст та 1-2\% - середніх. На сьогодні, велике значення має інформування суспільства, за допомогою проведення активної комунікаційної діяльності про особливості виробництва органічних про- дуктів, їх корисні властивості та значний внесок у збереження навколишнього середовища.

Масло вершкове органічне купують переважно такі категорії людей: освічені люди; середній та вищий сощіальні класи; купівельноспроможні, заможні люди; ті, хто піклуються про здоров'я сво$є \ddot{~ р о д и н и ~ т а ~} є$ орієнтованими на високоякісну продукцію; сім'ї з дітьми до 7 років [10, с. 5].

Українські респонденти розподіляються за групами відносно споживання різних видів органічної продукцї (табл. 1). Найбільше органічну молочну продукцію, в тому числі масло органічне, споживають люди віком 26-35 років і переважно жінки, які дбають про своє здоров'я та здоров'я своєї сім'ї та молоді люди віком 18-25 років, які хочуть мати здорове тіло та шкіру, піклуються про природу і слідують трендам, оскільки проблема забруднення постає дуже гостро й турбує кожного свідомого громадянина, а органічні ферми викидають від $30 \%$ менше парникових газів в атмосферу, ніж неорганічні. Найменше купують масло вершкове органічне літні люди (55 і більше років) - це зумовлено необізнаністю та високою ціновою категорією, порівняно зі звичайними видами масла вершкового.

Споживання масла вершкового органічного для населення України має мотиви та перешкоди (рис. 2).

В основному серед мотивів переважає бажання споживати натуральні продукти та вести здоровий спосіб життя. Перешкодами є недостатня поінформованість та відсутня державна підтримка щодо популяризації даного продукту і органічної продукції загалом. Важливим чинником, від якого залежить формування попиту крім екологічних чи суспільних цінностей є стан купівельної спроможності [12].

\begin{tabular}{|c|}
\hline Мотиви: \\
\hline • бажання споживати натуральні \\
продукти $(75$ \%); \\
• корисні властивості $(28 \%) ;$ \\
• естетичний зовнішній вигляд \\
етикетки (14 \%); \\
• інформативно багата упаковка \\
(9 \%); \\
• прихильність до здорового \\
способу життя (37 \%); \\
слідування прикладу знайомих \\
або рідних (5 \%)
\end{tabular}

\begin{tabular}{|c|}
\hline Перешкоди: \\
\hline • недовіра до виробників (45 \%); \\
• мала розповсюдженість \\
та вузький асортимент \\
в традиційних торговельних \\
мережах (41 \%); \\
• недостатня поінформованість \\
про споживчі переваги (56 \%); \\
відсутність державної підтримки \\
та популяризації даного продукту \\
(51 \%) \\
\end{tabular}

Рис. 2. Основні мотиви та перешкоди для покупки масла вершкового органічного в Україні 
Станом на сьогодні, ціна на масло вершкове органічне є завищеною, оскільки відсутня конкуренція та обмежений асортимент. За кордоном націнка на масло органічне вершкове може становити близько 15-30\%, натомість в Україні сягае більше $50 \%$ [10]. Вітчизняне мало вершкове органічне екстра в середньому коштуе 70-85 грн, масло вершкове екстра неорганічне українського виробника - 53-65 грн.

Основними каналами збуту масла вершкового органічного є спещіалізовані магазини або відділи супермаркетів, наприклад Сільпо, Novus, GoodWine, Ашан, METRO, МегаМаркет та інші. Більшість магазинів знаходиться у великих містах, також широко розповсюдженими е замовлення в онлайн-магазинах, де споживач може детально вивчити інформацію про продукцію, його переваги та придбати бажаний продукт.

Більшість споживачів готові купувати масло вершкове органічне за умов:

- забезпечення суворого контролю якості з боку державних органів;

- виробництва більш ширшого асортименту продукції та доступності її у торговельній мережі;

- незначного збільшення ціни на рівні 10-20\% відносно традиційної продукції.

Для того, щоб товарна категорія масла вершкового органічного на внутрішньому ринку була більш популяризованою необхідно застосовувати такі інструменти комунікації з споживачами:

- реклама - найбільш дієвий засіб налаштування контакту з потенційним покупцем, адже дозволяе створювати та підтримувати достатньо високий рівень поінформованості про товар, підвищуе імідж українських виробників органічних продуктів, крім того - це спосіб привернути увагу, зацікавленість, викликати бажання придбати органічне масло вершкове замість традиційного;

- пропаганда - організація громадської думки стосовного того, що при покупці даного продукту ви зможете вирішити ряд проблем. Цілями пропаганди є підвищення репутації підприемств, поширення важливих даних про товар через 3МI;
- стимулювання збуту - це заохочення споживачів придбати продукт за допомогою проведення короткострокових заходів (акційні пропозиції, дегустація, розіграші);

- прямий маркетинг - налагодження комунікацій з конкретною цільовою аудиторією з метою надання важливої інформації про масло вершкове органічне [13].

Висновки і пропозиції. Подальше формування та розвиток товарної категорії органічного масла є доцільним в Україні, через те, що це буде сприяти: відтворенню родючості грунтів та збереження навколишнього середовища; розвитку сільськогосподарських територій та підвищення рівня життя селян; прибутковості та ефективності с/г виробництва; забезпеченню споживчого ринку якісною, здоровою продукцією; зміцненню експортного потенціалу держави; поліпшенню іміджу українського виробника; забезпеченню продовольчої безпеки в Україні; покращення загального добробуту громадян країни.

Для џього варто ввести в дію наступні пропозиції:

1. Підвищувати інформованість населення про користь та безпечність масла вершкового органічного, про його цінність, споживчі переваги, позитивний вплив на економічну, соціальну та екологічну сфери діяльності.

2. Пропагувати здоровий спосіб життя, закликати до формування раціону харчування з переважаючою складовою в ньому органічних продуктів.

3. Залучати державні органи, інвестиції, екологічні асоціації та організації споживачів у процес формування ринку органічної продукції.

4. Вдосконалити, розширити нормативно-законодавчу базу, що стосуеться органічної продукції.

5. Перейняти досвід в організації продажу, побудові інфраструктури ринку, формування каналів збуту, пінової політики на масло вершкове органічне в країнах світу, що мають успіх в органічній галузі.

Отже, надані рекомендації, стосовно формування товарної категорії масло вершкове, за ї використання, можуть позитивно вплинути на подальший розвиток ринку органічної продукції.

\section{Список літератури:}

1. Виробництво TOB «Organic Milk». URL: https://organic-milk.com.ua/virobnitstvo/ (дата звернення: 10.04.2021).

2. Global Organic Dairy Market Outlook. Expert Market Research. 2020. URL: https://www.expertmarketresearch.com/ reports/organic-dairy-market (дата звернення: 11.04.2021).

3. Попит на органічну молочну продукцію у Франції. URL: https://www.eurocommerce.eu/ (дата звернення: 11.04.2021).

4. Зниження попиту на органічні продукти в Німеччині. AgroPortal. 2021. URL: http://organicstyle.agroportal.ua/ eksperti-nazvali-prichini-znizhennya-popitu-na-organichni-produkti-v-nimechchini (дата звернення: 11.04.2021).

5. FiBL Statistics - European and global organic farming statistics. 2020. URL: https://statistics.fibl.org/index.html (дата звернення: 12.04.2021).

6. Редих Е. Найбільші виробники органіки в Україні. Цензор.НЕT. 2018. URL: https://biz.censor.net/r3062840 (дата звернення: 12.04.2021).

7. Берсуцька С.Я., Козичева Т.О. Сучасний стан і перспективи розвитку ринку органічної продукції. Eкономічний вісник Донбасу. 2020. № 2(60). С. 165-171. DOI: https://doi.org/10.12958/1817-3772-2020-2(60)-165-172

8. Ковальчук С.В., Забурмеха С.М. Маркетингові цифрові технології у дослідженні споживачів органічної продукції. Marketing and Digital Technologies. 2017. T. 1. № 1. C. 34-49. DOI: https://doi.org/10.15276/mdt.1.1.2017.3

9. Органічне виробництво в Україні. URL: http://minagro.gov.ua/node/23346 (дата звернення: 16.04.2021).

10. Органічне виробництво і продовольча безпека : матеріали Міжнарод. наук.-практ. конф. «Органічне виробництво і продовольча безпека», м. Житомир : «Полісся», 2013. 492 с.

11. Мотиви для покупки органічної продукції в різних країнах світу. Agronews. 2020. URL: https://agronews.ua/ (дата звернення: 17.04.2021).

12. Вінюкова О.Б. Формування маркетингового інструментарію впровадження та просування органічної продукції на споживчі ринки. Причорнолорські еконолічні студї̈. 2018. В. 34. С. 52-57.

13. Семенда Д.К., Семенда О.В. Оцінка внутрішнього ринку органічної продукції України та поведінка споживачів на ньому. Молодий вчений. 2019. № 11(75). С. 609-613. DOI: https://doi.org/10.32839/2304-5809/201911-75-129 


\section{References:}

1. Vyrobnytstvo TOV «Organic Milk» [Production Ltd. Organic Milk]. Available at: https://organic-milk.com.ua/ virobnitstvo/ (accessed 10 April 2021).

2. Global organic dairy market outlook. (Expert Market Research, 2020). Available at: https://www.expertmarketresearch.com/reports/organic-dairy-market (accessed 11 April 2021).

3. Popyt na orhanichnu molochnu produktsiiu u Frantsii [Demand for organic dairy products in France]. Available at: https://www.eurocommerce.eu/ (accessed 11 April 2021).

4. Znyzhennia popytu na orhanichni produkty v Nimechchyni [Declining demand for organic products in Germany]. AgroPortal. 2021. Available at: http://organicstyle.agroportal.ua/eksperti-nazvali-prichini-znizhennya-popitu-naorganichni-produkti-v-nimechchini (accessed 11 April 2021).

5. FiBL Statistics - European and global organic farming statistic (2020). Available at: https://statistics.fibl.org/ index.html (accessed 12 April 2021).

6. Redykh E. (2018) Naibilshi vyrobnyky orhaniky v Ukraini [The largest producers of organic matter in Ukraine]. Tsenzor.NET. Available at: https://biz.censor.net/r3062840 (accessed 12 April 2021).

7. Bersutska S.Ya., Kozycheva T.O. (2020) Suchasnyi stan i perspektyvy rozvytku rynku orhanichnoi produktsii [Current state and prospects of organic market development]. Ekonomichnyi Visnyk Donbasu, vol. 2(60), pp. 165-171. Available at: https://doi.org/10.12958/1817-3772-2020-2(60)-165-172

8. Kovalchuk S.V., Zaburmekha Ye.M. (2017) Marketynhovi tsyfrovi tekhnolohii u doslidzhenni spozhyvachiv orhanichnoi produktsii [Marketing digital technologies in the study of consumers of organic products]. Marketing and Digital Technologies, vol. 1, no. 1, pp. 34-49. Available at: https://doi.org/10.15276/mdt.1.1.2017.3

9. Orhanichne vyrobnytstvo v Ukraini [Organic production in Ukraine]. Available at: http://minagro.gov.ua/ node/23346 (accessed 16 April 2021).

10. Orhanichne vyrobnytstvo i prodovolcha bezpeka [Organic production and food security]: Proceedings of the Mizhnarod. nauk.-prakt. konf. "Orhanichne vyrobnytstvo i prodovolcha bezpeka" (Zhytomyr, Polissia, 2013$), 492$ p.

11. Motyvy dlia pokupky orhanichnoi produktsii v riznykh krainakh svitu [Motives for buying organic products in different countries]. Agronews. 2020. Available at: https://agronews.ua/ (accessed 17 April 2021).

12. Viniukova O.B. (2018) Formuvannia marketynhovoho instrumentariiu vprovadzhennia ta prosuvannia orhanichnoi produktsii na spozhyvchi rynky [Formation of marketing tools for the introduction and promotion of organic products in consumer markets]. Prychornomorski Ekonomichni Studii, vol. 34, pp. 52-57.

13. Semenda D.K., Semenda O.V. (2019) Otsinka vnutrishnoho rynku orhanichnoi produktsii Ukrainy ta povedinka spozhyvachiv na nomu [Assessment of the domestic market of organic products of Ukraine and consumer behavior in it]. Young Scientist, vol. 11(75), pp. 609-613. Available at: https://doi.org/10.32839/2304-5809/2019-11-75-129 